\title{
Further studies on the changing composition of the digesta along the alimentary tract of the sheep
}

\author{
1. Total and non-protein nitrogen
}

\author{
By A. M. BADAWY,* ROSA M. CAMPBELL, D. P. CUTHBERTSON, \\ B. F. FELL AND W. S. MACKIE \\ Rowett Research Institute, Bucksburn, Aberdeenshire
}

(Received ro March 1958-Revised 9 Fune 1958)

\begin{abstract}
Boyne, Campbell, Davidson \& Cuthbertson (1956) found in the digesta of the small intestine of the sheep a considerable increase in the concentration of nitrogen in the organic matter, and also relative to the insoluble ash over that found in its abomasum. It was later found to be greatest in the proximal quarter and diminish distally throughout the rest of the small intestine. It was independent of the time interval from the last meal, at least up to the $12 \mathrm{~h}$ interval between feeds. Work was then planned to study further these changes in nitrogen content of the digesta in the abomasum and the small intestine relative to lignin as well as to insoluble ash as reference markers.
\end{abstract}

Lignin has a special position in relation to other reference markers, since it is a natural constituent of the ruminant's ration. The difficulty is that lignin is not well defined chemically, but in this laboratory it has been our experience (Walker 8 Hepburn, I954-5) that it can be fairly accurately estimated by the $72 \% \mathrm{H}_{2} \mathrm{SO}_{4}(\mathrm{w} / \mathrm{w})$ method modified by Ellis, Matrone \& Maynard (I946). The originators of the method consider that, in the sheep, lignin is not digested, though variations of $\pm 6 \%$ digestibility were recorded. Gray (1947) is in general agreement with these findings. Forbes, Elliot, Swift, James \& Smith (1946), using the same method, have also reported negligible digestibilities, but Thomas \& Smith (1954-5) using a different but direct method found digestibilities of up to $+9.9 \%$ for the lignin of heather. In rumendigestion studies in cows, Hale, Duncan \& Huffman ( $1947 b$ ) found mean digestion coefficients of $3 \cdot 1 \%$ for lignin, whereas the mean overall coefficient of digestion in the same animals was $21.5 \%$. Though the validity of the determination of the coefficients of digestibility in the reticulo-rumen is still the subject of controversy, the available evidence suggests that such digestion of lignin as may take place is probably mainly in the large intestine. But direct proof is lacking. Additional evidence of occasional relatively high overall digestibilities is found in the work of Ely, Kane, Jacobson \& Moore (I953) using the method of Ellis et al. (1946), who found overall digestion coefficients in cows of up to $+16.0 \%$. Balch (1957), using a method which he had previously found with his colleagues to give low to negative digestibilities, found in another experiment on cows total digestibility values ranging from $-17 \cdot 3$

* Present address: Faculty of Agriculture, University of Alexandria, Alexandria, Egypt. 
to $+24.4 \%$. It may be that the character of the diet, the age and breed of animal, and day-to-day variations in the passage of the lignin affect the outcome of balance studies. Most workers have felt fairly confident in its use; for example, Hale et al. $(1947 a, b)$ and Balch (1957) have used the lignin-ratio technique for studying the decomposition of food constituents in the reticulo-rumen.

In our laboratory total nitrogen and non-protein nitrogen relative to lignin and insoluble ash were studied in the first instance both in sheep shot in the frontal region of the skull and bled and in sheep with cannulas near the pylorus or with the flow of digesta exteriorized in a part of the small intestine without about $2 \mathrm{ft}$. of the pylorus.

Further observations (Badawy, Campbell, Cuthbertson \& Fell, 1957) showed that the mode of killing the animal had to be taken into account in interpreting the results, and the findings in such shot and bled sheep have therefore been compared with those obtained from sheep anaesthetized with pentobarbitone sodium in which the contents were removed from the tied-off sectioned portions of tract.

\section{EXPERIMENTAL}

\section{Experiment I}

The changes in nitrogen content along the alimentary tract of six I-year-old Greyface wethers were studied along with those of dry matter, ash, steam-volatile fatty acids (v.F.A.) and energy, relative to lignin. The changes in v.F.A. and energy are described in the accompanying paper of Badawy, Campbell, Cuthbertson \& Mackie (1958a).

The animals were divided into three groups of two animals each. Each group was given a different diet.

Group I was fed on the following ration daily: $45^{\circ} \mathrm{g}$ hay at 7 a.m.; $225 \mathrm{~g}$ concentrates ( 2 parts linseed meal and $x$ part crushed oats) at I I a.m. and $45^{\circ} \mathrm{g}$ hay at 4 p.m.

Group 2 was fed on the following ration daily divided into two equal lots at 7 a.m. and 7 p.m.: $400 \mathrm{~g}$ hay; $400 \mathrm{~g}$ concentrates ( 20 parts ground maize, 3 parts decorticated extracted groundnut meal, I part dried yeast). To the ration for each day $5 \mathrm{~g}$ $\mathrm{Na}_{2} \mathrm{HPO}_{4} \cdot 12 \mathrm{H}_{2} \mathrm{O}$ and $5 \mathrm{~g} \mathrm{NaCl}$ were added.

Group 3 was fed on the following ration daily divided into two equal lots and given at 7 a.m. and 7 p.m.: $400 \mathrm{~g}$ hay; $400 \mathrm{~g}$ concentrates ( 2 parts linseed meal and I part crushed oats).

The sheep were kept in separate pens on the appropriate dietary regime for 2 weeks before they were put into the metabolic cages, where $24 \mathrm{~h}$ excretions of faeces were collected over a period of 6 days. Dry matter, ash, nitrogen, lignin and energy were estimated in the dried faecal material and in the food. The sheep generally ate their ration for the period within $\mathrm{I} h$ but any residues were weighed. The sheep were killed serially, one on each of 6 days. Killing took place at i a.m., $4 \mathrm{~h}$ after the last meal, which consisted of hay only in the first group and hay and concentrates in the other two groups. The animals were shot in the frontal region of the skull with a humane killer and bled by cutting the throat. The abdominal cavity was opened at once and single (at points $I$ and 8) or double string ligatures were tied round the following structures with as little disturbance of contents as possible: (I) the oesophagus 
immediately in front of the cardia; (2) the junction between the reticulum and the omasum; (3) the junction between the omasum and the abomasum; (4) the duodenum immediately adjacent to the pylorus; $(5)$ at numerous points along the small intestine to prevent mixing of the contents at different levels, with subsequent pooling of the contents into those representing equal lengths; $(6)$ the ileo-caecal valve; $(7)$ the junction between the caecum and colon; and (8) the junction between the colon and the rectum. The parts were separated and cleaned from adhering tissues and their contents weighed.

Dry matter and total nitrogen were estimated on the wet material, and ash and lignin on the dried material.

\section{Experiment 2}

In a further study of the changes in nitrogen content of the digesta in the abomasum and the small intestine, two groups of six Blackface ewes were used. Each group was killed as in Exp. r. All the sheep were fed on hay ad lib. at 7 a.m. and 4 p.m. and with $225 \mathrm{~g}$ concentrates ( 2 parts linseed meal and I part crushed oats) at I I a.m. daily. The first group was killed at 9 a.m., 2 h after the 7 a.m. feed, and the second at 9 a.m., I $7 \mathrm{~h}$ after the last feed (4 p.m. the previous day). The procedure for obtaining the digesta was as in Exp. I, but limited to the abomasum and the small intestine, the latter being divided into four approximately equal portions. Total nitrogen, non-protein nitrogen and dry matter were estimated on the fresh material. The dried materials from each organ in each group were pooled in proportion to the dry-matter content of the organ. On the pooled samples dry matter, lignin and ash were estimated.

\section{Experiment 3}

Since these first two experiments confirmed in general the previous findings of Boyne et al. (1956), the changes were studied in the digesta obtained from living sheep with one or more cannulas or with the flow of digesta exteriorized in a part of the small intestine.

Cannulated sheep. A 2-year-old Greyface wether was fitted with two Perspex cannulas in the duodenum, one just caudal to the pylorus and the second at the iliac flexure after the entrance of the common bile and pancreatic duct. Six samples were withdrawn from each cannula at $2 \mathrm{~h}$ intervals on two separate occasions.

A Blackface wether was fitted with two Perspex cannulas, one in the duodenum after the entrance of the common bile and pancreatic duct and the other in the ileum, I ft. from the ileo-caecal valve.

Dry matter, total nitrogen and non-protein nitrogen were estimated on the wet samples withdrawn from these two sheep. The dried material from the samples of each cannula was pooled and dry matter, ash and lignin were estimated.

Sheep with an exteriorized flow of digesta in a part of the small intestine. The flow of a part of the small intestine in three sheep was exteriorized as follows. The abdominal cavity was opened at the selected area, the small intestine was sectioned and the two cut ends were closed by continuous sutures. A Perspex cannula with a suitably curved shaft was inserted into each end and exteriorized through stab wounds in the abdominal wall and the two cannulas were then joined by a wide-bore Polythene tube. Finally, the operation wound was closed. The flow was collected 14 days later from the anterior 
cannula every ro min throughout a $12 \mathrm{~h}$ or $24 \mathrm{~h}$ period, and a $10 \%$ sample was taken, the remainder from each to min period being then reintroduced through the posterior cannula. The method was essentially that described by Markowitz (1949).

Sheep no. I with the duodenal flow exteriorized before the common bile and pancreatic duct entrance (just caudal to the pylorus) was made available through the kindness of Mr J. P. Hogan who also was making studies on nitrogen absorption. The flow from this sheep represented the digesta coming from the abomasum. It was measured every hour for $24 \mathrm{~h}$, beginning at $7 \mathrm{a} . \mathrm{m}$. (with the morning feed) and ending at 7 a.m. next morning.

Sheep no. 2 had the duodenal flow exteriorized after the common bile and pancreatic duct entrance. The flow from this sheep was measured every hour for $12 \mathrm{~h}$ on three occasions, beginning at 7 a.m. with the morning feed and ending at 7 p.m. just before the evening feed.

Sheep no. 3 had the jejunal flow exteriorized just beyond the duodenum. The flow from this sheep was measured every hour for $\mathrm{I} 2 \mathrm{~h}$ on three occasions as with sheep no. 2 .

Dry matter, total nitrogen and non-protein nitrogen were estimated in the hourly wet samples. For the first sheep the dried material from the day samples as well as that from the night samples was pooled in proportion to the dry-matter content of the total flow in each hour. In the second sheep the dried material from each $\mathrm{I} 2 \mathrm{~h}$ collection was pooled in proportion to the dry-matter content of the flow in each hour. In the third sheep dried material from every hourly sample was pooled into two samples each representing a $6 \mathrm{~h}$ period. Dry matter, ash, insoluble ash and lignin were estimated in the pooled samples.

Management. The cannulated sheep and the sheep with an exteriorized flow were given $600 \mathrm{~g}$ hay and $400 \mathrm{~g}$ concentrates ( 2 parts linseed meal and I part crushed oats) in two equal lots at 7 a.m. and 7 p.m. daily. The three sheep with an exteriorized flow of the small intestine were kept in metabolic cages and $24 \mathrm{~h}$ excretions of faeces collected over a period of 6 days. The collections for the estimation of the lignin flow during the $24 \mathrm{~h}$ and of the total digestion of lignin in $24 \mathrm{~h}$ were done on different days. Dry matter and total nitrogen were estimated in the wet faeces and the food. Ash, insoluble ash and lignin were estimated in the dried faeces as well as in the food. Thus it was hoped that assessments of the total nitrogen absorbed and the main locations of absorption could be determined.

\section{Experiment 4}

Since the foregoing experiments failed to reveal such a marked rise in the nitrogen content of the small intestine as had previously been observed, the effect of fright on the nitrogen content of the digesta was simulated by administering an adrenaline injection. It was done in a 2-year-old Greyface wether fitted with a cannula in the duodenum just after the common bile and pancreatic duct entrance. Three samples of the digesta were withdrawn from the cannula on 3 successive days at i I a.m. On the following 2 days $\mathrm{I} \mathrm{mg}$ adrenaline hydrochloride was injected into the jugular vein at II a.m. on each day as I ml. of a $0.1 \%$ solution. Immediately after injection on the Ist day four samples from the cannula were collected at $10 \mathrm{~min}$ intervals. On the 
2nd day seven samples were collected. On the 3 rd day the sheep was killed by shooting and bleeding at I a.m. in the usual way and the abdomen opened. A ligature was tied round the duodenum immediately below the pylorus, and the abomasum and small intestine were cleaned from the adhering tissues. The small intestine was then divided into five parts consisting of (I) the duodenum up to the position of the cannula, (2), (3), (4) and (5) being the remainder of the small intestine divided into quarters. The contents were collected as previously described. Dry matter, total nitrogen and non-protein nitrogen were estimated on the wet samples. This sheep had been fed on the same diet and in the same way as the other cannulated sheep.

\section{Experiment 5}

Eight Cheviot wether lambs (mean weight, $23 \mathrm{~kg}$ ) were kept in separate pens for 2 weeks and fed on hay and concentrates in two equal lots at 7 a.m. and 7 p.m. The animals were killed on two separate days $3-4 \mathrm{~h}$ after feeding. Four lambs were shot in the frontal region of the skull by humane killer and bled by cutting the throat, and the other four were anaesthetized by pentobarbitone sodium given intravenously, and the required portions of the digestive tract were removed. The digesta from the abomasum and the proximal and distal portions of the small intestine were analysed for total nitrogen, non-protein nitrogen and lignin. In addition, air-dried, Leishman-stained smears of intestinal contents were made from the main divisions of the bowel from the abomasum to the colon.

Always as soon as the intestinal tract was isolated and the parts were tied, and before the removal of the contents, representative portions of the intestine $2-3$ in. long were taken from the duodenum, jejunum and ileum. The specimens were immersed immediately in adequate volumes of $10 \%(\mathrm{v} / \mathrm{v})$ formol-saline each in a separate jar. After $\mathrm{I}-2 \mathrm{~h}$, suitable portions were cut out with a sharp blade and the fixation of the selected tissue was continued for I week either in 10\% formol-saline or in formol corrosive (Lendrum, 194I). After routine processing the blocks were embedded in paraffin wax and sectioned at $5 \mu$. Sections were stained with haematoxylin and eosin, with Periodic Acid Schiff-haemalum and with Southgate's mucicarmine.

\section{Chemical methods}

The methods used were the same as those reported in the earlier paper (Boyne $e t$ al. 1956). In addition, non-protein nitrogen was estimated in the filtrate by a microKjeldahl method after precipitation with $20 \%(\mathrm{w} / \mathrm{v})$ trichloroacetic acid, final strength $5 \%$. Lignin was estimated by the $72 \%$ sulphuric-acid method as modified by Ellis et al. (1946).

\section{RESULTS}

Exps. I and 2. Changes in nitrogen content of the digesta in the abomasum and the small intestine of sheep killed by humane killer and bled

The concentration of total nitrogen on a wet-material basis increased considerably from the reticulo-rumen sac to the omasum, which was followed by a sharp decrease in the abomasum. Total nitrogen as a percentage of the organic matter (Table $\mathrm{I}$ ) or 
as a ratio to lignin (Table 2 ) was almost the same in the contents of the reticulo-rumen sac and of the omasum; in the abomasum, however, and to a very much more pronounced extent in the proximal half of the small intestine, the total nitrogen as a percentage of the organic matter or of the lignin was increased, to be followed by

Table 1. Exp. I. Percentage concentrations of total nitrogen and lignin in the contents of the alimentary tract of the three groups of two sheep

(See also Table r, Badawy et al. 1958a)

\begin{tabular}{|c|c|c|c|c|c|c|c|}
\hline \multirow[b]{2}{*}{$\begin{array}{l}\text { Basis of calculation } \\
\text { and group no. }\end{array}$} & \multicolumn{7}{|c|}{ Site } \\
\hline & $\begin{array}{l}\text { Reticulo- } \\
\text { rumen sac }\end{array}$ & Omasum & Abomasum & $\begin{array}{l}\text { Proximal } \\
\text { small } \\
\text { intestine }\end{array}$ & $\begin{array}{c}\text { Distal } \\
\text { small } \\
\text { intestine }\end{array}$ & Caecum & Color \\
\hline Wet material & & & Nitrogen & & & & \\
\hline $\mathbf{I}$ & 0.266 & 0.460 & 0.189 & 0.719 & 0.327 & 0.219 & 0.268 \\
\hline 2 & 0.389 & 0.761 & 0.339 & 0.535 & 0.293 & 0.337 & 0.471 \\
\hline $\begin{array}{l}3 \\
\text { Mean }\end{array}$ & $\begin{array}{l}0.534 \\
0.396\end{array}$ & $\begin{array}{l}0.941 \\
0.721\end{array}$ & $\begin{array}{l}0.308 \\
0.279\end{array}$ & $\begin{array}{l}0.731 \\
0.662\end{array}$ & $\begin{array}{l}0.332 \\
0.317\end{array}$ & $\begin{array}{l}0.3 I I \\
0.289\end{array}$ & $\begin{array}{l}0.421 \\
0.386\end{array}$ \\
\hline $\begin{array}{l}\text { As percentage of } \\
\text { concentration in } \\
\text { reticulo-rumen sac }\end{array}$ & & 182 & $70 \cdot 5$ & 167 & $80 \cdot 1$ & $73 \cdot 0$ & $97 \cdot 5$ \\
\hline \multicolumn{8}{|l|}{ Dry matter } \\
\hline$I$ & $2 \cdot 34$ & $2 \cdot 25$ & $2 \cdot 10$ & $7 \cdot 32$ & $3 \cdot 94$ & I.93 & $I \cdot 95$ \\
\hline 2 & 3.05 & $2 \cdot 60$ & 3.07 & $6 \cdot 88$ & $4 \cdot 13$ & $2 \cdot 60$ & $2 \cdot 77$ \\
\hline 3 & $3 \cdot 66$ & 4.00 & $3 \cdot 17$ & $6 \cdot 83$ & 3.88 & $2 \cdot 37$ & $2 \cdot 35$ \\
\hline Mean & 3.02 & $2 \cdot 95$ & $2 \cdot 78$ & 7.01 & 3.98 & $2 \cdot 30$ & $2 \cdot 36$ \\
\hline $\begin{array}{l}\text { As percentage of } \\
\text { concentration in } \\
\text { reticulo-rumen sac }\end{array}$ & & $97 \cdot 7$ & $92 \cdot I$ & 232 & 132 & $76 \cdot 1$ & $78 \cdot 1$ \\
\hline \multicolumn{8}{|l|}{ Organic matter } \\
\hline I & $2 \cdot 5^{8}$ & 259 & $4 \cdot 74$ & $8 \cdot 52$ & 4.74 & $2 \cdot 29$ & $2 \cdot 29$ \\
\hline 2 & $3 \cdot 3 \mathrm{I}$ & $2 \cdot 75$ & $3 \cdot 78$ & $8 \cdot 09$ & 4.93 & $2 \cdot 97$ & $3 \cdot 15$ \\
\hline 3 & $3 \cdot 96$ & 4.43 & $4 \cdot 31$ & $7 \cdot 84$ & $4 \cdot 71$ & $2 \cdot 73$ & $2 \cdot 70$ \\
\hline Mean & $3 \cdot 29$ & $3 \cdot 26$ & $4 \cdot 28$ & $8 \cdot 15$ & 479 & $2 \cdot 66$ & $2 \cdot 71$ \\
\hline As percentage of & & $99^{\circ} \mathrm{I}$ & 130 & 248 & 146 & 80.9 & $82 \cdot 4$ \\
\hline
\end{tabular}

concentration in reticulo-rumen sac

Wet material

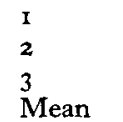

Dry matter

I
2
3
Mean

a sharp decrease in the distal half of the small intestine and caecum. No further decrease was noticed in the colon. The results agree with those already reported by Boyne et al. (1956) from this Institute.

In the second experiment in which the small intestine was divided into four parts, nitrogen concentration, as a percentage of the organic matter and in relation to lignin (Table 3), similarly increased considerably from the abomasum to the proximal quarter 
of the small intestine and then decreased progressively in the second, third and fourth quarters. The increase of nitrogen concentration was mainly in the form of non-protein nitrogen. The difference between total nitrogen and non-protein nitrogen concentrations in the different parts in question was statistically significant. Though protein nitrogen was significantly higher in the first quarter of the small intestine than in the abomasum or in the second quarter, and no significant difference in protein nitrogen existed between the second, third and fourth quarters, it is recognized that the proportion of non-protein nitrogen will be affected by any continuing hydrolysis before precipitation of the protein.

Although the nitrogen concentrations in the corresponding parts of the group killed $2 \mathrm{~h}$ after the last feed were somewhat higher than in the group killed $\mathrm{I} 7 \mathrm{~h}$ after the last feed the differences were not significant.

Table 2. Exp. 1. Ratios ( $g / g)$ of total nitrogen to lignin in the contents of the alimentary tract of the three groups of two sheep

\begin{tabular}{cccccccc}
\multicolumn{8}{c}{ Site } \\
Group no. & $\begin{array}{c}\text { Reticulo- } \\
\text { rumen }\end{array}$ & sac & Omasum & Abomasum & $\begin{array}{c}\text { Proximal } \\
\text { small } \\
\text { intestine }\end{array}$ & $\begin{array}{c}\text { Distal } \\
\text { small } \\
\text { intestine }\end{array}$ & $\begin{array}{c}\text { Caecum } \\
\text { Colon }\end{array}$ \\
I & 0.13 & 0.10 & 0.22 & 1.05 & 0.29 & 0.08 & 0.08 \\
3 & 0.18 & 0.23 & 0.35 & 2.71 & 0.35 & 0.12 & 0.12 \\
Mean & 0.20 & 0.20 & 0.21 & 0.84 & 0.25 & 0.09 & 0.09 \\
As percentage of & 0.17 & 0.18 & 0.26 & 1.53 & 0.30 & 0.10 & 0.10 \\
ratio in & & 106 & 153 & 900 & 176 & 59 & 59
\end{tabular}

reticulo-rumen sac

Table 3. Exp. 2. Concentrations of dry matter, ash, lignin, total nitrogen, non-protein nitrogen and protein nitrogen in the contents of the abomasum and the small intestine (divided into four equal lengths) of sheep, and ratios of the nitrogen fractions to lignin

(Six sheep/group)

\begin{tabular}{|c|c|c|c|c|c|c|c|c|c|}
\hline & \multirow[b]{2}{*}{$\begin{array}{c}\text { Dry } \\
\text { matter } \\
(\%)\end{array}$} & \multirow[b]{2}{*}{$\begin{array}{l}\text { Ash as } \\
\text { percentage } \\
\text { of dry } \\
\text { matter }\end{array}$} & \multirow[b]{2}{*}{$\begin{array}{l}\text { Lignin as } \\
\text { percentage } \\
\text { of organic } \\
\text { matter }\end{array}$} & \multicolumn{2}{|c|}{ Total nitrogen } & \multicolumn{2}{|c|}{$\begin{array}{l}\text { Non-protein } \\
\text { nitrogen }\end{array}$} & \multicolumn{2}{|c|}{ Protein nitrogen } \\
\hline & & & & $\begin{array}{l}\text { As per- } \\
\text { centage of } \\
\text { organic } \\
\text { matter }\end{array}$ & $\begin{array}{l}\text { Ratio } \\
\text { to } \\
\text { lignin } \\
(\mathrm{g} / \mathrm{g})\end{array}$ & $\begin{array}{l}\text { As per- } \\
\text { centage of } \\
\text { organic } \\
\text { matter }\end{array}$ & $\begin{array}{l}\text { Ratio } \\
\text { to } \\
\text { lignin } \\
(\mathrm{g} / \mathrm{g})\end{array}$ & $\begin{array}{l}\text { As per- } \\
\text { centage of } \\
\text { organic } \\
\text { matter }\end{array}$ & $\begin{array}{l}\text { Ratio } \\
\text { to } \\
\text { lignin } \\
(\mathrm{g} / \mathrm{g})\end{array}$ \\
\hline \multicolumn{10}{|c|}{ Group I, killed $2 \mathrm{~h}$ after last feed } \\
\hline $\begin{array}{l}\text { Abomasum } \\
\text { Small intestine }\end{array}$ & $8 \cdot 93$ & 10.40 & $32 \cdot 0$ & $4 \cdot 11$ & 0.13 & $1 \cdot 25$ & 0.04 & $2 \cdot 86$ & 0.09 \\
\hline I & $10 \cdot 16$ & 10.50 & $\mathrm{II} \cdot 4$ & $9 \cdot 64$ & 0.85 & $5 \cdot 34$ & 0.47 & 4.30 & 0.38 \\
\hline 2 & $10 \cdot 31$ & $12 \cdot 04$ & $23 \cdot 5$ & $7 \cdot 60$ & 0.32 & $4 \cdot 45$ & 0.19 & $3 \cdot 16$ & 0.14 \\
\hline 3 & $10 \cdot 33$ & 13.56 & $25 \cdot 8$ & 6.91 & 0.27 & 3.71 & 0.14 & 3.20 & 0.12 \\
\hline 4 & $8 \cdot 63$ & I $4 \cdot 08$ & $36 \cdot 7$ & $5 \cdot 02$ & 0.14 & $2 \cdot 22$ & 0.06 & $2 \cdot 80$ & 0.08 \\
\hline \multicolumn{10}{|c|}{ Group 2 , killed i 7 h after last feed } \\
\hline $\begin{array}{l}\text { Abomasum } \\
\text { Small intestine }\end{array}$ & $9 \cdot 07$ & $13 \cdot 60$ & $48 \cdot 7$ & 3.28 & 0.07 & 0.83 & 0.02 & $2: 45$ & 0.05 \\
\hline $\mathrm{I}$ & 9.07 & I I*I 4 & $9 \cdot 2$ & $8 \cdot 63$ & 0.94 & $5 \cdot 19$ & 0.56 & 3.44 & 0.37 \\
\hline 2 & $9^{6} 61$ & I 3.68 & 15.7 & $6 \cdot 74$ & 0.43 & $4 \cdot 38$ & 0.28 & $2 \cdot 36$ & 0.15 \\
\hline 3 & $7 \cdot 16$ & $14 \cdot 67$ & $37{ }^{\circ}$ & $5 \cdot 06$ & 0.14 & $2 \cdot 84$ & 0.08 & $2 \cdot 22$ & 0.06 \\
\hline 4 & $7 \cdot 30$ & 14.31 & 43.9 & 3.90 & 0.09 & $x \cdot 62$ & 0.04 & $2 \cdot 28$ & 0.05 \\
\hline
\end{tabular}


It will be seen from these experiments that nitrogen relative to organic matter and to lignin increased very considerably in the first quarter of the small intestine and decreased distally thereafter.

The overall digestion of lignin (Exp. I) ranged from 6.8 to $28.8 \%$, mean $22.1 \%$ (see Badawy et al. 1958a). It was of interest that despite this variability in digestion the percentage of lignin in the dry matter of the faeces was remarkably constant in all six sheep despite considerable differences in intake. Though such high apparent digestibilities are rare and were not found in Exp. 3 they are not, as we have shown, unknown in the literature. In view of the findings of Hale et al. (I947 b) previously referred to, it is considered unlikely that any digestion of lignin, which may have taken place, would seriously affect the interpretation of the analyses of digesta up to the ileo-caecal valve.

\section{Exps. 3 and 4. Changes in nitrogen content of the digesta obtained from living sheep fitted with cannulas or from sheep with an exteriorized flow of the small intestine}

The mean percentages of total nitrogen, non-protein nitrogen and protein nitrogen on an organic-matter basis in the digesta obtained from sheep with cannulas or with an exteriorized flow of the small intestine along with their ratios to lignin are shown

Table 4. Exp. 3. Mean percentages of total nitrogen, non-protein nitrogen and protein nitrogen in relation to organic matter and lignin in contents of small intestine of sheep with cannulas or with an exteriorized flow

\begin{tabular}{|c|c|c|c|c|c|c|c|c|}
\hline \multirow[b]{2}{*}{ Treatment } & \multirow[b]{2}{*}{$\begin{array}{c}\text { Sheep } \\
\text { no. } \\
\text { in groups }\end{array}$} & \multirow[b]{2}{*}{$\begin{array}{l}\text { Place of cannula } \\
\text { or exteriorization }\end{array}$} & \multicolumn{2}{|c|}{ Total nitrogen } & \multicolumn{2}{|c|}{$\begin{array}{l}\text { Non-protein } \\
\text { nitrogen }\end{array}$} & \multicolumn{2}{|c|}{ Protein nitrogen } \\
\hline & & & $\begin{array}{l}\text { As per- } \\
\text { centage of } \\
\text { organic } \\
\text { matter }\end{array}$ & $\begin{array}{l}\text { Ratio } \\
\text { to } \\
\text { lignin } \\
(\mathrm{g} / \mathrm{g})\end{array}$ & $\begin{array}{l}\text { As per- } \\
\text { centage of } \\
\text { organic } \\
\text { matter }\end{array}$ & $\begin{array}{c}\text { Ratio } \\
\text { to } \\
\text { lignin } \\
(\mathrm{g} / \mathrm{g})\end{array}$ & $\begin{array}{l}\text { As per- } \\
\text { centage of } \\
\text { organic } \\
\text { matter }\end{array}$ & $\begin{array}{l}\text { Ratio } \\
\text { to } \\
\text { lignin } \\
(\mathrm{g} / \mathrm{g})\end{array}$ \\
\hline \multirow[t]{4}{*}{ Cannulated } & I & $\begin{array}{l}\text { Duodenum before entrance } \\
\text { of bile and pancreatic duct }\end{array}$ & 4.07 & 0.13 & $I \cdot 6 I$ & 0.05 & $2 \cdot 46$ & 0.08 \\
\hline & & $\begin{array}{l}\text { Duodenum after entrance } \\
\text { of bile and pancreatic duct }\end{array}$ & $4 \cdot 44$ & 0.20 & $\mathbf{I} \cdot 87$ & 0.09 & $2 \cdot 57$ & 0.12 \\
\hline & 2 & $\begin{array}{l}\text { Duodenum after entrance } \\
\text { of bile and pancreatic duct }\end{array}$ & $4 \cdot 48$ & 0.19 & $2 \cdot 14$ & 0.09 & $2 \cdot 34$ & 0.10 \\
\hline & & Ileum & $2 \cdot 53$ & 0.07 & $0 \cdot 86$ & 0.02 & $x \cdot 67$ & 0.04 \\
\hline \multirow[t]{3}{*}{$\begin{array}{l}\text { Exteriorized } \\
\text { flow }\end{array}$} & I & $\begin{array}{l}\text { Duodenum before entrance } \\
\text { of bile and pancreatic duct }\end{array}$ & $5 \cdot 20$ & 0.22 & $2 \cdot 08$ & 0.09 & $3 \cdot 13$ & 0.13 \\
\hline & 2 & $\begin{array}{l}\text { Duodenum after entrance } \\
\text { of bile and pancreatic duct }\end{array}$ & $4 \cdot 39$ & 0.22 & $\mathrm{r} \cdot 87$ & 0.09 & $2 \cdot 53$ & 0.13 \\
\hline & 3 & Jejunum & $4 \cdot 86$ & 0.26 & $2 \cdot 14$ & $0 \cdot 1 \mathrm{I}$ & $2: 73$ & 0.15 \\
\hline
\end{tabular}

in Table 4. In sheep no. $I$ of this group which was fitted with two cannulas, one before and the other after the entrance of the common bile and pancreatic duct, the percentage of total nitrogen on an organic dry-matter basis, was somewhat higher in the digesta obtained from the cannula posterior to entry of the common bile and pancreatic duct, than in the digesta obtained from the cannula in the first part of the duodenum, and the ratios to lignin were rather more pronounced. The difference was more obvious in non-protein nitrogen than in protein nitrogen and more so when the values were 
related to lignin. The difference between the materials obtained from the two cannulas was not significant statistically. The ratio of total nitrogen to lignin in the flow from the first cannula was similar to that noted for the contents of the abomasum in the second experiment.

In sheep no. 2 fitted with two cannulas, one in the duodenum after the common bile and pancreatic duct entrance and the second in the ileum I ft. from the ileo-caecal valve, the concentration of nitrogen, especially non-protein nitrogen as a percentage of the organic matter, was significantly lower in the digesta obtained from the ileal cannula than in those obtained from the duodenal cannula. This difference was more pronounced in terms of lignin. In this area there would therefore seem to be a marked absorption of the nitrogen added in the first quarter.

Table 5. Exp. 3. Total amounts ( $g$ ) of the different constituents in the digesta of sheep passing the different places of exteriorization of flow

\begin{tabular}{|c|c|c|c|c|c|c|c|c|}
\hline $\begin{array}{l}\text { Sheep } \\
\text { no. }\end{array}$ & $\begin{array}{c}\text { Place of } \\
\text { exteriorization }\end{array}$ & $\begin{array}{l}\text { Sampling no. and } \\
\text { hour of collection }\end{array}$ & $\begin{array}{c}\text { Total } \\
\text { nitrogen }\end{array}$ & $\begin{array}{l}\text { Protein } \\
\text { nitrogen }\end{array}$ & $\begin{array}{l}\text { Non- } \\
\text { protein } \\
\text { nitrogen }\end{array}$ & Lignin & $\begin{array}{l}\text { Insoluble } \\
\text { ash }\end{array}$ & $\begin{array}{l}\text { Dry } \\
\text { matter }\end{array}$ \\
\hline I & $\begin{array}{l}\text { Duodenum before } \\
\text { entrance of bile and } \\
\text { pancreatic duct }\end{array}$ & $\begin{array}{l}\text { (I) } 7 \text { a.m. }-7 \text { p.m. } \\
7 \text { p.m. }-7 \text { a.m. } \\
\text { Amount passing } \\
\text { in } 24 \mathrm{~h}\end{array}$ & $\begin{array}{r}9 \cdot 88 \\
10 \cdot 31 \\
20 \cdot 19\end{array}$ & $\begin{array}{r}5 \cdot 95 \\
6 \cdot 16 \\
12 \cdot 11\end{array}$ & $\begin{array}{l}3.93 \\
4.14 \\
8.08\end{array}$ & $\begin{array}{l}44 \cdot 8 \\
45 \cdot 8 \\
90 \cdot 6\end{array}$ & $\begin{array}{l}3 \cdot 89 \\
4 \cdot 37 \\
8 \cdot 26\end{array}$ & $\begin{array}{l}23 r \cdot 4 \\
236 \cdot 4 \\
467 \cdot 8\end{array}$ \\
\hline 2 & $\begin{array}{l}\text { Duodenum after } \\
\text { entrance of bile and } \\
\text { pancreatic duct }\end{array}$ & $\begin{array}{l}\text { (I) } 7 \text { a.m. }-7 \text { p.m. } \\
\text { (2) } 7 \text { a.m. }-7 \text { p.m. } \\
\text { (3) } 7 \text { a.m. }-7 \text { p.m. } \\
\text { Approx. amount } \\
\text { passing in } 24 \mathrm{~h}\end{array}$ & $\begin{array}{r}9 \cdot 63 \\
10 \cdot 17 \\
8 \cdot 10 \\
18 \cdot 60\end{array}$ & $\begin{array}{r}5 \cdot 94 \\
5 \cdot 56 \\
4 \cdot 99 \\
\text { II.00 }\end{array}$ & $\begin{array}{l}3 \cdot 68 \\
4 \cdot 61 \\
3 \cdot 11 \\
7 \cdot 60\end{array}$ & $\begin{array}{l}46 \cdot 5 \\
48 \cdot 0 \\
33 \cdot 8 \\
85 \cdot 5\end{array}$ & $\begin{array}{r}\text { II I I } 2 \\
4 \cdot 08 \\
5 \cdot 94 \\
14 \cdot 09\end{array}$ & $\begin{array}{l}279 \cdot 9 \\
270 \cdot 3 \\
213 \cdot 6 \\
522 \cdot 5\end{array}$ \\
\hline 3 & Jejunum & $\begin{array}{l}\text { (1) } 7 \text { a.m. - I p.m. } \\
\text { I p.m. }-7 \text { p.m. } \\
\text { (2) } 7 \text { a.m. - } ~ \\
\text { I p.m. }-7 \text { p.m. } \\
\text { (3) } 7 \text { a.m.-I p.m. } \\
\text { I p.m. }-7 \text { p.m. } \\
\text { Approx. amount }\end{array}$ & $\begin{array}{r}2 \cdot 81 \\
4 \cdot 35 \\
5 \cdot 50 \\
6 \cdot 13 \\
4 \cdot 24 \\
4 \cdot 84 \\
18 \cdot 59\end{array}$ & $\begin{array}{r}1 \cdot 40 \\
2 \cdot 46 \\
3 \cdot 16 \\
3 \cdot 79 \\
2 \cdot 26 \\
2 \cdot 79 \\
10 \cdot 57\end{array}$ & $\begin{array}{l}I \cdot 42 \\
I \cdot 90 \\
2 \cdot 34 \\
2 \cdot 35 \\
I \cdot 98 \\
2 \cdot 05 \\
8 \cdot 02\end{array}$ & $\begin{array}{r}9 \cdot 6 \\
15 \cdot 8 \\
21 \cdot 7 \\
24 \cdot 9 \\
15 \cdot 5 \\
20 \cdot 1 \\
71 \cdot 7\end{array}$ & $\begin{array}{l}0 \cdot 74 \\
1 \cdot 11 \\
3 \cdot 59 \\
3 \cdot 21 \\
1 \cdot 81 \\
2 \cdot 09 \\
8 \cdot 37\end{array}$ & $\begin{array}{r}63 \cdot 7 \\
102 \cdot 1 \\
139 \cdot 5 \\
148 \cdot 5 \\
104 \cdot 7 \\
122 \cdot 3 \\
453 \cdot 9\end{array}$ \\
\hline
\end{tabular}

In the sheep with the exteriorized flow, it can be seen from Table 4 that there was but a slight rise in the concentration of nitrogen in the digesta obtained from the different exteriorized flows-the second of which was not more than about $5 \mathrm{ft}$. beyond the pylorus-over that of the abomasal contents of the killed sheep (Tables 1 and 2).

The mean hourly flow from the sheep with exteriorized flow from the duodenum before the common bile and pancreatic duct entrance was $462 \mathrm{ml}$; in the sheep with exteriorized flow after the common bile and pancreatic duct entrance it was $3^{6}{ }_{5} \mathrm{ml}$.; and in the sheep with exteriorized flow in the jejunum near the duodenum it was $342 \mathrm{ml}$. The amounts of the different constituents in the digesta passing the different places of exteriorization on the different sampling occasions and in $24 \mathrm{~h}$ are shown in Table 5. From this table it can be seen that the amount of lignin was closely related to the amount of dry matter, whereas insoluble ash was not so closely related.

The overall percentage digestion of lignin in the three sheep was respectively 3.7 , I I. 2 and II.4\% (Table 6). These values are for sheep with exteriorized flow but 
obtained at a time when flow was not disturbed. During the periods of collection of flow, the amount of lignin passing the point of periodic collection in $24 \mathrm{~h}$ was less than that passed in the faeces for the equivalent but undisturbed period.

The amounts of total nitrogen passing the duodenum before and after the entrance of the common bile and pancreatic duct and the jejunum in $24 \mathrm{~h}$ in these prepared animals were $20.19,18.60$ and $18.59 \mathrm{~g}$, respectively, compared with $19.48 \mathrm{~g}$ in the food consumed daily (Table 6).

Table 6. Exp. 3. Composition of food consumed and faeces voided daily by the three sheep with exteriorized flow of the small intestine

(Means of 6-day periods)

\begin{tabular}{|c|c|c|c|c|c|}
\hline Sheep no. & $\begin{array}{l}\text { Total } \\
\text { nitrogen } \\
\text { (g) }\end{array}$ & $\begin{array}{l}\text { Lignin } \\
\text { (g) }\end{array}$ & $\begin{array}{c}\text { Insoluble } \\
\text { ash } \\
\text { (g) }\end{array}$ & $\begin{array}{c}\text { Ratio, } \\
\text { total nitrogen: } \\
\text { lignin } \\
(\mathrm{g} / \mathrm{g})\end{array}$ & $\begin{array}{c}\text { Ratio, } \\
\text { total nitrogen: } \\
\text { insoluble ash } \\
(\mathrm{g} / \mathrm{g})\end{array}$ \\
\hline \multicolumn{6}{|c|}{ Food } \\
\hline Each & $19 \cdot 48$ & 117.5 & $8 \cdot 39$ & 0.17 & $2 \cdot 32$ \\
\hline \multicolumn{6}{|c|}{ Faeces } \\
\hline I & 6.04 & $\operatorname{Ir} 3 \cdot 2$ & II 14 & 0.05 & 0.54 \\
\hline 2 & $5 \cdot 57$ & 104.3 & $7 \cdot 10$ & 0.05 & 0.78 \\
\hline 3 & $6 \cdot 01$ & 104.2 & $8 \cdot 52$ & 0.06 & $0.7 \mathrm{I}$ \\
\hline
\end{tabular}

Apparent digestion of lignin: sheep no. I, 3.7 ; sheep no. 2, I I.2; sheep no. $3,11 \cdot 4 \%$.

\section{Effect of adrenaline injection and killing on the nitrogen content of the duodenal digesta}

From Table 7 it can be seen that adrenaline in the amount used had no effect on the nitrogen content of the digesta obtained from a duodenal cannula. The concentration of nitrogen on a dry-matter basis in the digesta obtained from the duodenum (up to the place of the cannula) of this adrenaline-injected sheep, after killing by shooting and bleeding, was about double that in the digesta obtained from the cannula and collected under apparently normal in vivo conditions or after adrenaline injection.

Table 7. Exp. 4. Mean percentages of total nitrogen and non-protein nitrogen in dry matter in normal samples taken from a sheep, in samples taken from it after intravenous injection of adrenaline (all from a duodenal cannula), and in the duodenal digesta of the same sheep after killing (see p. 370)

\begin{tabular}{lcc}
\multicolumn{1}{c}{ Sample } & $\begin{array}{c}\text { Total } \\
\text { nitrogen }\end{array}$ & $\begin{array}{c}\text { Non-protein } \\
\text { nitrogen }\end{array}$ \\
$\begin{array}{l}\text { Normal } \\
\text { After I mg adrenaline hydrochloride } \\
\text { injected intravenously }\end{array}$ & $3 \cdot 40$ & $\mathbf{1} \cdot 39$ \\
$\begin{array}{l}\text { After slaughter by shooting } \\
\text { and bleeding }\end{array}$ & $6 \cdot 58$ & $\mathrm{r} \cdot 36$ \\
& & $3 \cdot 8 \mathrm{I}$
\end{tabular}

There was a still greater rise in the nitrogen concentration of the digesta in the remaining part of the first quarter of the small intestine, which was followed by the usual progressive decrease distally (Table 8 ). 
Vol. I2

It was obvious from this experiment that either the digestive processes behaved abnormally when sampling from the cannula occurred, or that some abnormal change occurred at death, but since there was no evidence that the cannula was the cause, further investigation was concentrated on the mode of death.

Table 8. Exp. 4. Contents and percentages of dry matter, total nitrogen and non-protein nitrogen in the abomasum and the small intestine (divided into five parts) of the sheep quoted in Table 7

\begin{tabular}{|c|c|c|c|c|c|c|c|}
\hline \multirow[b]{2}{*}{ Site } & \multicolumn{2}{|c|}{ Contents } & \multicolumn{2}{|c|}{$\begin{array}{c}\text { Total } \\
\text { nitrogen }(\%)\end{array}$} & \multicolumn{2}{|c|}{$\begin{array}{l}\text { Non-protein } \\
\text { nitrogen }(\%)\end{array}$} & \multirow{2}{*}{$\begin{array}{l}\text { Non-protein } \\
\text { nitrogen as } \\
\text { percentage of } \\
\text { total nitrogen }\end{array}$} \\
\hline & $\begin{array}{l}\text { Weight } \\
\text { (g) }\end{array}$ & $\begin{array}{c}\text { Dry } \\
\text { matter } \\
(\%)\end{array}$ & $\begin{array}{c}\text { On wet } \\
\text { basis }\end{array}$ & $\begin{array}{l}\text { On dry- } \\
\text { matter } \\
\text { basis }\end{array}$ & $\begin{array}{c}\text { On wet } \\
\text { basis }\end{array}$ & $\begin{array}{l}\text { On dry- } \\
\text { matter } \\
\text { basis }\end{array}$ & \\
\hline Abomasum & $603 \cdot 4$ & $12 \cdot 14$ & 0.238 & I.96 & 0.067 & 0.55 & $28 \cdot 1$ \\
\hline Small intestine & & & & & & & \\
\hline $\begin{array}{l}\text { I (up to the } \\
\text { (cannula) }\end{array}$ & $10 \cdot 8$ & $8 \cdot 12$ & 0.534 & $6 \cdot 5^{8}$ & 0.309 & $3 \cdot 8 \mathrm{I}$ & $57^{\circ} 9$ \\
\hline $\begin{array}{l}2 \text { (rest of the } \\
\text { first quarter) }\end{array}$ & $27 \cdot 0$ & $1 I \cdot 45$ & $x \cdot 042$ & $9 \cdot 10$ & 0.664 & 5.80 & 63.7 \\
\hline 3 (second quarter) & $54^{-8}$ & $7 \cdot 9 \mathrm{I}$ & $0.53^{8}$ & $6 \cdot 80$ & 0.379 & $4 \cdot 79$ & 70.4 \\
\hline 4 (third quarter) & $284 \cdot 5$ & $7 \cdot 96$ & 0.209 & $2 \cdot 63$ & 0.089 & I. 12 & $42 \cdot 6$ \\
\hline 5 (last quarter) & $263 \cdot 7$ & 9.79 & 0.229 & $2 \cdot 34$ & 0.069 & 0.71 & $30 \cdot 1$ \\
\hline
\end{tabular}

Exp. 5. Comparison between the nitrogen content of the digesta obtained from the abomasum and the small intestine of slaughtered sheep and sheep under pentobarbitonesodium anaesthesia

The total nitrogen content in relation to organic matter and to lignin in the digesta from four shot and bled sheep followed the same trend as previously found. There was the usual considerable rise from the abomasum through the first half of the small intestine followed by the usual decrease in the second half (Table 9). In the other

Table 9. Exp. 5. Contents of total nitrogen and non-protein nitrogen on organic-matter basis in the abomasum and small intestine of both killed and anaesthetized (pentobarbitone sodium) sheep, and their ratios to lignin

\begin{tabular}{|c|c|c|c|c|c|}
\hline \multirow[b]{2}{*}{ Site } & \multicolumn{2}{|c|}{ Total nitrogen } & \multicolumn{3}{|c|}{ Non-protein nitrogen } \\
\hline & $\begin{array}{l}\text { As percentage } \\
\text { of organic } \\
\text { matter }\end{array}$ & $\begin{array}{l}\text { Ratio to } \\
\text { lignin } \\
(\mathrm{g} / \mathrm{g})\end{array}$ & $\begin{array}{c}\text { As percentage } \\
\text { of organic } \\
\text { matter }\end{array}$ & $\begin{array}{l}\text { Ratio to } \\
\text { lignin } \\
(\mathrm{g} / \mathrm{g})\end{array}$ & $\begin{array}{c}\text { As percentage } \\
\text { of total } \\
\text { nitrogen }\end{array}$ \\
\hline \multicolumn{6}{|c|}{ Killed (four sheep) } \\
\hline Abomasum & $2 \cdot 48$ & 0.30 & $1 \cdot+3$ & 0.14 & $45^{\circ} 4$ \\
\hline \multicolumn{6}{|l|}{ Small intestine } \\
\hline Proximal half & $5 \cdot 58$ & $\mathrm{I} \cdot \mathrm{OI}$ & 3.78 & 0.68 & $67 \cdot 8$ \\
\hline Distal half & $2 \cdot 89$ & 0.30 & $1 \cdot 59$ & 0.17 & $54^{\circ} 9$ \\
\hline \multicolumn{6}{|c|}{ Anaesthetized (three sheep)* } \\
\hline Abomasum & $2 \cdot 77$ & 0.21 & $I \cdot 20$ & 0.09 & 43.4 \\
\hline \multicolumn{6}{|l|}{ Small intestine } \\
\hline Proximal half & $3 \cdot 62$ & 0.27 & $2 \cdot 33$ & 0.18 & $64 \cdot 2$ \\
\hline Distal half & $2 \cdot 13$ & 0.16 & $x \cdot O I$ & 0.08 & $47 \cdot 4$ \\
\hline
\end{tabular}


group of three sheep from which the digesta were obtained under pentobarbitone anaesthesia, the total nitrogen concentration in the first half of the small intestine still showed a definite rise, but it was not so great as in the shot and bled animals. The marked decrease was also noticed in the distal half of the small intestine. The main increment in nitrogen from abomasum to small intestine was present in the form of non-protein nitrogen.

\section{Histological observations}

Examination of the Leishman-stained smears of the intestinal contents of the sheep in Exp. 5 showed a clear distinction between the specimens from the sheep that had been shot and bled and those from the anaesthetized animals. In the former group the duodenal contents contained large quantities of damaged but easily recognizable columnar cells, in epithelial sheets, smaller groups, or singly. There were also cell fragments and degenerated cells. Macroscopically, these duodenal smears had a distinct purplish colour which contrasted with the flat blue of the other specimens, including the smears of duodenal contents from the anaesthetized sheep. Intestinal contents, apart from the duodenum, contained only occasional cells.

Histological studies on the same animals revealed a distinctive shedding of the epithelium of the villi of the intestines of the sheep that had been shot and bled. This change was either absent, or present to a very slight degree, in the eviscerated intestine of anaesthetized animals. There was a gradation in the degree of damage, with the peak usually in the duodenum but occasionally in the jejunum. In the severest cases the connective tissue cores of the villi were stretched and distorted and were at the tip totally devoid of all cells.

\section{DISCUSSION}

Although lignin does not always behave as an inert reference substance, it has on the whole many advantages over other markers. It is considered that there are no clear indications that would prevent its use, particularly from the omasum to the ileo-caecal junction, and it may even be legitimate to use it for the reticulo-rumen, but obviously with great caution. The nitrogen:lignin ratios in those portions of the digestive tract studied indicate that the increase in nitrogen concentration in both the abomasum and the proximal half of the small intestine must be attributed to the addition of nitrogen to these two parts. It will be seen from Table 2 that there was little or no difference in the total nitrogen:lignin ratios in the reticulum and omasum, but that the figures for the abomasum suggest that there was a $44 \%$ increase from the omasum presumably due to digestive juice, although other observations indicate that there is not much nitrogenous material to be found in pouch juice in sheep (private communication from Dr A. T. Phillipson). The increase in nitrogen concentration on a wet-material basis in the omasum can be attributed to the dehydration which takes place in that organ, and of this a fuller account is given by Badawy et al. ( $\left.195^{8 b}\right)$.

When the small intestine was divided into four parts the increase in total nitrogen was found mainly in the first quarter with a progressive decrease distally. These results are in agreement with the earlier observations of Boyne et al. (1956) on the sheep at this Institute, and with those of Raynaud (1955 $a, b)$ who found a marked increase in 
nitrogen concentration in the duodenal digesta of cattle killed $24 \mathrm{~h}$ after their last feed. This increase in nitrogen in the small intestine at the time of examination was found to be mainly in the form of non-protein nitrogen as judged from the ratio of nonprotein nitrogen to lignin. The change was brought about most probably by addition of non-protein nitrogen and by hydrolysis of added protein, and not by a faster rate of absorption of non-nitrogenous compounds as Raynaud (1955a) suggested, since these ratios indicate a more pronounced increase than the concentrations in the dry matter would alone suggest.

The considerable decrease in nitrogen concentration in the distal parts of the tract, as indicated by the fall in the ratios to lignin, we attributed to absorption. Boyne $e$ al. (1956) from their preliminary investigations of the combined bile and pancreatic secretions concluded that these secretions could not account for the bulk of the increase in nitrogen in the first part of the small intestine. On the other hand, Mosenthal (I9I I) considered that in the dog some $35 \%$ of the nitrogen in the digesta of the small intestine came from the succus entericus. His observation was derived from a cannulated isolated loop of intestine obtained from to to 20 in. of lower ileum. Hogan (r957) has reported from this Institute a definite addition of nitrogen to a washed-out loop of small intestine, but the nitrogen was mainly as protein and not largely nonprotein nitrogen as found in the present experiments. The addition of nitrogen through bile and pancreatic juice we found to be small. It may be that in Hogan's isolated loop, and in that of Mosenthal, the source of the nitrogen was in part the proteins of lymph. It would account for the low content of non-protein nitrogen.

In the sheep with two cannulas in the duodenum, one before and one after the entrance of the common bile and pancreatic duct, the concentration of nitrogen in the chyme obtained in vivo from the cannula after the ampulla of Vater was somewhat higher than in that obtained from the cannula before that entrance. But the ratios of nitrogen to lignin were much lower than in the killed sheep whose digesta were studied up to that point, and also in the anaesthetized sheep, though in the latter the ratio was calculated on contents from a half of the length of the small intestine. This increase in nitrogen to just beyond the ampulla of Vater could be attributed to the bile, pancreatic and intestinal secretions, and might have been greater had there not been presumably some absorption of the digestion products taking place simultaneously. That the difference in non-protein nitrogen between these two sites was greater than the difference in protein nitrogen, might be due to the degree of protein hydrolysis occurring, or to the entrance of bile or to both, since non-protein nitrogen was found to make up $80 \%$ of the total nitrogen in the bile obtained from the gall-bladders of a series of slaughtered sheep, though the bile actually entering the duodenum might have been of different composition. The mean percentage of total nitrogen in the bile on a dry-matter basis was 3.37 and of non-protein nitrogen 2.72 , and in the sheep in these experiments the gall-bladders were reasonably full at slaughter. The small difference between the concentration of nitrogen before and after the ampulla of Vater was more pronounced when related to lignin (Table 4 ).

In the sheep with two cannulas, one in the duodenum after the entrance of the common bile and pancreatic duct and the other in the ileum, the nitrogen concentration 
in the duodenal chyme was significantly higher than in the ileal chyme. The difference was more considerable when expressed in terms of lignin (Table 4). Such changes could be attributed to absorption.

In the sheep with an exteriorized flow there was no noticeable difference in the concentration of nitrogen in the digesta obtained from different places of exteriorization and none of the values, when related to lignin, were similar in magnitude to those found in the first quarter of the small intestine of the slaughtered animals. As might be expected, the individual variations were not great, since the three sheep were kept under the same dietary regime. Therefore, in so far as examined in vivo, the intestinal secretions had no considerable effect in increasing the nitrogen concentration in the digesta of the small intestine of the living sheep, at least up to the first few $\mathrm{ft}$. of the jejunum.

Within each sheep with exteriorized flow of the small intestine, the amount of lignin passing the place of exteriorization over a certain period of time was closely related to the amount of dry matter passing. Since insoluble ash was not as closely related to dry matter as lignin, this finding suggests that insoluble ash was passing at a less regular rate relative to dry matter. Lignin can in this sense be considered as a more reliable reference substance than insoluble ash in detecting the extent of absorption and secretion in the small intestine. But in the three sheep with exteriorized flows, the amounts of lignin passing the places of exteriorization (in $24 \mathrm{~h}$ ) were less for each sheep than the mean amounts of lignin excreted in the faeces (Tables 5 and 9). Therefore, the rates of flow of the digesta found at the time of examination must be considered to have been less than the normal rate, possibly owing to the disturbance to the animal incurred when hourly samples were taken. The differences, however, were not large. One would naturally expect that the amounts of lignin passing these openings in $24 \mathrm{~h}$ would not be less than the amounts excreted in the faeces daily, and possibly might be even more if lignin were digested posterior to the places of exteriorization such as in the caecum and colon. It has already been pointed out that the collections for the estimation of lignin flow in $24 \mathrm{~h}$ and for lignin excreted in the faeces were done on different days.

The considerable increase in nitrogen concentration found to occur in the first quarter (about $20 \mathrm{ft}$. in length in the dead animal, less in the living) of the small intestine of killed sheep has therefore not been found to exist in living sheep fitted with permanent cannulas, or with exteriorized flows of part of the small intestine in so far as examined distally, that is, for the first $2 \mathrm{ft}$. from the pylorus. This finding has been briefly reported (Badawy, Campbell \& Cuthbertson, 1957). Since the nitrogen concentration in the digesta obtained from the duodenum of a cannulated sheep after killing was considerably higher than in the normal samples obtained in vivo from the duodenal cannula in the same sheep before killing, it was suspected that the shock of killing might in part be the cause of the increase in nitrogen concentration. On the other hand, the technique of sampling by cannula might be suspected to lead to a reduced secretion or a reduced flow, but subsequent evidence did not support this effect as the main cause. It seemed highly probable that the shock of killing caused an excessive liberation of adrenaline. But fright simulated by the injection of $\mathrm{r} \mathrm{mg}$ 
adrenaline intravenously appeared to cause no significant alteration in the composition of the digesta on the two occasions when it was investigated. As further investigation pointed to shedding of the epithelium as a source of the extra nitrogen, further work on adrenaline was postponed. Wright, Jennings, Florey \& Lium (I940) have described a marked shedding of epithelium after administration of eserine and acetylcholine.

Mucus and shed mucosal epithelium might then be the main cause of the rise in protein nitrogen and the shedding of the epithelium might also lead to nonprotein nitrogen passing into the lumen of the tract. Rapid hydrolysis could account for the marked rise in non-protein nitrogen. That hydrolysis is a factor in causing a rise in the proportion of non-protein nitrogen was demonstrated by the lower proportion (40-50\%) found in the more rapidly precipitated material obtained from the cannulas than from post-mortem material. Our colleague, Dr Hywel Jones, has found that non-protein nitrogen represented $49.5 \%$ of the total nitrogen in the upper small-intestinal contents removed immediately at death and treated with trichloroacetic acid (final strength $5 \%$ ). After $4 \mathrm{~h}$ at room temperature the percentage of non-protein nitrogen had risen to $68.6 \%$.

Preliminary investigations have now been made of the composition of the abomasal and intestinal contents, in relation to the histology of the gut wall, to determine how far shedding of epithelium or other structural changes might account for the findings, even when the gut and its contents were removed from the animal within a few minutes of death. Smears of the digesta obtained from killed and bled, and from anaesthetized (pentobarbitone sodium) sheep, did not show an appreciable amount of shedding, except in the first quarter of the small intestine of the shot sheep. Florey, Wright \& Jennings (194I) in their review of the secretions of the intestine consider that there is no doubt that there is a constant and considerable desquamation of epithelial cells into the lumen of the intestine. Such activity in the first part of the intestine is also of interest in relation to the observation of McMinn (1954), who noted in the cat a rapid degree of cellular turnover in the first part of the small intestine. Florey et al. (1941) have even suggested that the succus entericus is derived from cast-off epithelial cells rather than as a secretion from the mucosa. Cajori $(1933,1935)$ and Pierce, Nasset \& Murlin (1935) are in agreement that intestinal juices, which probably contain cellular fragments detached from the mucosa, usually have a greater hydrolytic activity than the centrifuged juices. It thus seemed feasible that the shock of killing might have enhanced the casting off of intestinal epithelial cells particularly in the first quarter of the small intestine. On the other hand, the nature of the change observed suggested a distinctive type of damage rather than an enhanced physiological shedding. The observations reported in Exp. 5 demonstrate that, though there was only a slight change in the epithelium of the abomasum in sheep shot in the frontal region and then bled, there was a marked shedding of the epithelium of the intestines and caecum, but more particularly in the first quarter of the small intestine. In these animals there was the usual marked rise of nitrogen in the proximal part of the intestine, a rise primarily due to a parallel rise in non-protein nitrogen-presumably in part due to the rapid hydrolysis of the mucosal cellular debris, and possibly also to the liberation 
of the products of hydrolysis previously in course of absorption through the now shed epithelium. The rapidity of the process is most striking and may also lead to passage of lymph through the wall of the bowel into its lumen.

In the gut of the animal anaesthetized intravenously with pentobarbitone sodium there was a definitely smaller rise in nitrogen, though some rise still took place and there was much less damage to the mucosal surface.

This communication deals with the conditions found in cannulated, shot and anaesthetized sheep. It might be supposed that the damage associated with shooting is due to a direct cerebral effect, perhaps analogous to Claude Bernard's 'piqûre'. This is probably not so, since further unpublished observations show that the effects of shooting in the frontal region and bleeding on the intestinal mucosa, and on the nitrogen:lignin ratio of the intestinal contents are reproduced in sheep killed by shooting through the cervical vertebrae or by a lethal dose of pentobarbitone. It may be that the shedding is a terminal event not found in the tract of animals eviscerated under pentobarbitone anaesthesia and whose tissues are immediately fixed.

\section{SUMMARY}

I. Studies on the composition of the digesta of the alimentary tract of thirty-four sheep have been made, particularly in respect of total and non-protein nitrogen.

2. Observations on the composition of the digesta of the various parts of the alimentary tract of sheep previously reported in respect of total nitrogen, have been confirmed and these changes have now been described relative to lignin. Though lignin is not a perfect reference marker it is considered that any digestion which may have taken place up to the ileo-caecal valve is not likely to have affected the conclusions arrived at regarding digestion in the abomasum and small intestine.

3. Relative to lignin the ratios indicated an increase of nitrogen in the abomasum, but the increase was much greater in the proximal half of the small intestine than in the distal half. In an experiment in which the small intestine was divided into four parts, protein nitrogen and non-protein nitrogen concentrations increased considerably in the first quarter of the small intestine and decreased progressively in the other three quarters. Lignin ratios indicated that the non-protein nitrogen contributed a greater proportion to the increase in the small intestine than did protein nitrogen though the latter also rose. This considerable rise in nitrogen concentration in the first quarter of the small intestine was not found in living sheep fitted with permanent cannulas, or with an exteriorized flow of the small intestine when the cannulas were located within the first few feet from the pylorus.

4. Adrenaline given intravenously had no effect on the nitrogen content of the digesta obtained from a sheep with a duodenal cannula.

5. A comparison of the histology of the mucosa of the small intestine of sheep shot in the frontal region with a humane killer and then bled (the usual method of slaughter), with specimens removed from sheep under pentobarbitone anaesthesia revealed that, whereas the mucosa remained relatively intact when removed under this anaesthetic, there was a very marked shedding of the epithelium in the animals that had been shot 
and bled. This difference might be expected to account for part of the observed rise in nitrogen.

We are indebted to Dr A. T. Phillipson and Mr R. W. Ash for performing the surgical operations necessary, and to $\mathrm{Mr}$ L. E. Vowles for his postoperative care. We also thank Miss K. A. Smith for technical assistance.

\section{REFERENCES}

Badawy, A. M., Campbell, R. M. \& Cuthbertson, D. P. (1957). Congr. int. Nutr. Iv. Paris. Résumés des Communications, p. 70.

Badawy, A. M., Campbell, R. M., Cuthbertson, D. P. \& Fell, B. F. (1957). Nature, Lond., I80, 756. Badawy, A. M., Campbell, R. M., Cuthbertson, D. P. \& Mackie, W. S. (1958a). Brit. F. Nutr. 12, 384. Badawy, A. M., Campbell, R. M., Cuthbertson, D. P. \& Mackie, W. S. (1958b). Brit. F. Nutr. 12, 391. Balch, C. C. (1957). Brit. F. Nutr. II, 2 I3.

Boyne, A. W., Campbell, R. M., Davidson, J. \& Cuthbertson, D. P. (1956). Brit. F. Nutr. 10, 325.

Cajori, F. A. (1933). Amer. F. Physiol. ro4, 659.

Cajori, F. A. (1935). F. biol. Chem. ro9, I 59.

Ellis, G. H., Matrone, G. \& Maynard, L. A. (1946). F. Anim. Sci. 5, 285.

Ely, R. E., Kane, E. A., Jacobson, W. C. \& Moore, L. A. (1953). F. Dairy Sci. 36, 346.

Florey, H. W., Wright, R. D. \& Jennings, M. A. (1941). Physiol. Rev. 21, 36.

Forbes, E. B., Elliot, R. F., Swift, R. W., James, W. H. \& Smith, V. F. (1946). F. Anim. Sci. 5, 298. Gray, F. V. (1947). F. exp. Biol. 24, I5.

Hale, E. B., Duncan, C. W. \& Huffman, C. F. (1947a). F. Nutr. 34, 733.

Hale, E. B., Duncan, C. W. \& Huffman, C. F. $(1947 b)$. $\mathscr{F} . ~ N u t r .34,747$.

Hogan, J. P. (1957). F. Physiol. 139, ${ }_{2} P$.

Lendrum, A. C. (194I). F. Path. Bact. 52, 132.

Markowitz, J. (1949). Experimental Surgery, and ed. London: Baillière, Tindall and Cox.

McMinn, R. M. H. (1954). F. Anat., Lond., 88, 527.

Mosenthal, H. O. (r91 I). F. exp. Med. r3, 3 rg.

Pierce, H. B., Nasset, E. S. \& Murlin, J. R. (1935). F. biol. Chem. 108, 239.

Raynaud, P. (1955a). Arch. Sci. physiol. 9, 35.

Raynaud, P. (I955b). Arch. Sci. physiol. 9, 83 .

Thomas, B. \& Smith, A. N. (1954-5). F. agric. Sci. 45, 104.

Walker, D. M. \& Hepburn, W. R. (1954-5). F. agric. Sci. 45, 298.

Wright, R. D., Jennings, M. A., Florey, H. W. \& Lium, R. (1940). Quart. F. exp. Physiol. 30, 73. 